\title{
ASPECTS OF REPRODUCTIVE BIOLOGY AND ABUNDANCE OF AFRICAN BONYTONGUE (HETEROTIS NILOTICUS) IN GREAT KWA RIVER, NIGERIA
}

\author{
${ }^{* 1}$ Ikot, N. U., ${ }^{2}$ Ekanem, S. B. and ${ }^{3}$ Eyo, V. O. \\ ${ }^{* 1,2}$ Department of Zoology and Environmental Biology, University of Calabar, P.M.B.1115 Calabar, Nigeria \\ "Phone: +2348064761822 Email: ikanobio@gmail.com \\ ${ }^{2}$ Phone: +2348036725853 Email: sbe2005@yahoo.com \\ ${ }^{3}$ Department of Fisheries and Aquaculture, Nigeria Maritime University, Okerenkoko, Delta State, Nigeria \\ Phone:+2348065162221 Email: sirvick2003@yahoo.com
}

\begin{abstract}
This study was conducted to evaluate some aspects of the reproductive biology of the African Bonytongue Heterotis niloticus from the Great Kwa River, Cross River State Nigeria with the view to encourage conservation and rational measures for sustainable management of the species. A total of 62 matured H. niloticus were sampled and their gonadosomatic index (GSI), hepatosomatic index (HSI), condition factor, fecundity and egg diameter ( $\mathrm{mm}$ ) were studied in other to determine the spawning season of the fish. Gonadosomatic index and hepatosomatic index showed an inverse relationship during spawning seasons. Total length (TL-cm) ranged between $47.1 \mathrm{~cm}-76.2 \mathrm{~cm}$ and total weight $(\mathrm{TW}-\mathrm{g}$ ) ranged between $4300 \mathrm{~g}-1169 \mathrm{~g}$ with sex ratio of 1:1.2 (male: female) revealing a dominant female population. Fecundity ranged from 511 oocytes $(48.4 \mathrm{~cm} \mathrm{TL} ; 1.69 \mathrm{~kg}$ wt, $5.9 \mathrm{~g}$ gonad weight) to 7822 oocytes $(69.3 \mathrm{~cm} \mathrm{TL}, 3.11 \mathrm{~kg}$ wt. $14.9 \mathrm{~g}$ gon ad weight). The regression equation derived from the scattered diagram in the relationship between fecundity and total weight, total length gonadosomatic index and length-weight is; $F=6.6231 \mathrm{TW}^{0.837}, \mathrm{R}^{2}=0.2456 ; \mathrm{F}=5.1112 \mathrm{TL}^{1.6367}, \mathrm{R}^{2}=0.1606 ; \mathrm{F}=10680 \mathrm{GSI}{ }^{0.9276}, \mathrm{R}^{2}=0.6567$; $\mathrm{TW}=0.4072 \mathrm{TL}^{2.0987}, \mathrm{R}^{2}=0.7533$, the relationship were significant $(\mathrm{p}<0.05)$. Fecundity and ovary weight relationship showed a positive correlation coefficient of 1 . The highest egg diameter $(0.92 \pm 0.01)$ was recorded in May and other months with corresponding high gonadosomatic index performance to confirm spawning period. In view to encourage conservation by investigating measures for sustainable management of the species, this study observed that $H$. niloticus spawns throughout the year.
\end{abstract}

Keywords: fecundity, egg, gonadosomatic index, Great Kwa River, Heterotis niloticus, hepatosomatic index

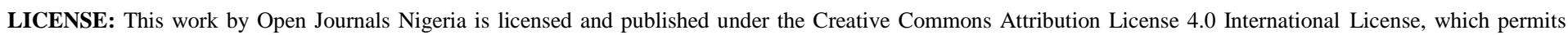
unrestricted use, distribution, and reproduction in any medium, provided this article is duly cited.

COPYRIGHT: The Author(s) completely retain the copyright of this published article.

OPEN ACCESS: The Author(s) approves that this article remains permanently online in the open access (OA) mode.

QA: This Article is published in line with "COPE (Committee on Publication Ethics) and PIE (Publication Integrity \& Ethics)". 


\section{INTRODUCTION}

The Great Kwa River in recent times has witness a significant increase in human activities which had traditionally centred on artisanal fisheries, aquaculture and small-scale farming along the coastal regions. The Great Kwa River is one of the tributaries of the Cross River Estuary and its basin has undoubtedly influenced by urban development especially the increasing numbers of houses and factories built around the freshwater and mangrove swamps of the river, the expansion of the University of Calabar which has almost encroach into the river floodplain. Agricultural farms are the primary engagement witnessed at the coastal regions of the Great Kwa River. The surrounding mangrove vegetations have suffered human interferences resulting in breeding ground and habitat loss, degradation and undoubtedly many fish species including Heterotis niloticus are threatened and endangered Mustapha (2010). Due to general environmental degradation which includes oil spillages, pollution and destruction of mangrove swamps, this species has lost an estimated $60 \%$ of its previous breeding and nursery habitat in Nigeria with subsequent reduction in populations (Bake \& Sadiku, 2005; Offem et al., 2011).

Heterotis niloticus has no origin in Great kwa rather was introduced by escaping from a flooded pond in Cameroon into the wild (Ekanem, 2000) and spread into Cross River State and Akwa Ibom State in Nigeria. The size and flesh of this fish species attracts fishers, aquaculturist and consumers.

The African bony-tongue is one of the accepted food fish species in Nigeria inland waters. It may be due to the firmness in the flesh texture and the large size. This species is widely distributed in rivers, creeks and freshwater lakes of Western and Central Africa (Levêque et al., 1990). In Cross River Basin highest body weight that has been recorded is $8 \mathrm{~kg}$ and length of 1.2 meters, but the highest length and weight reported in Northern Nigeria waters was 1 meter and 6kg, respectively (Offem et al., 2008, Reed et al., 1967). In Northern Nigeria, the fish had prevalence during the months of July and August each year (rainy season), with rising river level (Ekwu, 2008). Heterotis niloticus has become popular in fish farming in Nigeria today due to its fast growth rate, ability to withstand stress, ability to survive in water with low oxygen content, which has endeared it to many fish farmers (Akegbejo-Samsons et al, 2004; Adite et al., 2006).

\section{AIM AND OBJECTIVES}

In this study, the abundance, condition factor, fecundity and gonadosomatic index were investigated to estimate the species abundance, wellbeing, and the reproductive capacity indices of the Heterotis niloticus in the Great Kwa River, with the view to encouraging conservation and rational measures for sustainable management of the species. The study also aimed at determining the spawning time of $H$. niloticus using gonadosomatic index hepatosomatic index and egg size in the Great Kwa River. The decrease in observable stock and the quest to investigate the breeding season of Heterotis niloticus justify this research.

\section{MATERIAL AND METHODS STUDY AREA}

The Great Kwa River is a freshwater body which lies between latitude $4^{\circ} 45^{\prime}$ and $5^{\circ} 12^{\prime} \mathrm{N}$ longitude $8^{0} 20^{\prime}$ and $8^{0} 31^{\prime} \mathrm{E}$ (CRBDA, 1982) is located in a forested belt, and surrounded by Rain forest, freshwater swamp and mangrove swamp. The tidal flow from the Cross River Estuary, occasionally increases the salinity and permits some aquatic organisms from the estuary to flow to the river with tidal movement. Three sampling station were chosen; Station-1: Obufa Esuk, Station-2: Esuk Otu and Station-3: Eusk Atimbo to cover the entire river for 
collection of landings from local artisanal fishers. The collection stations are indicated in figure 1. Sampling was done forth nightly from January to December to cover all the seasons of the year.

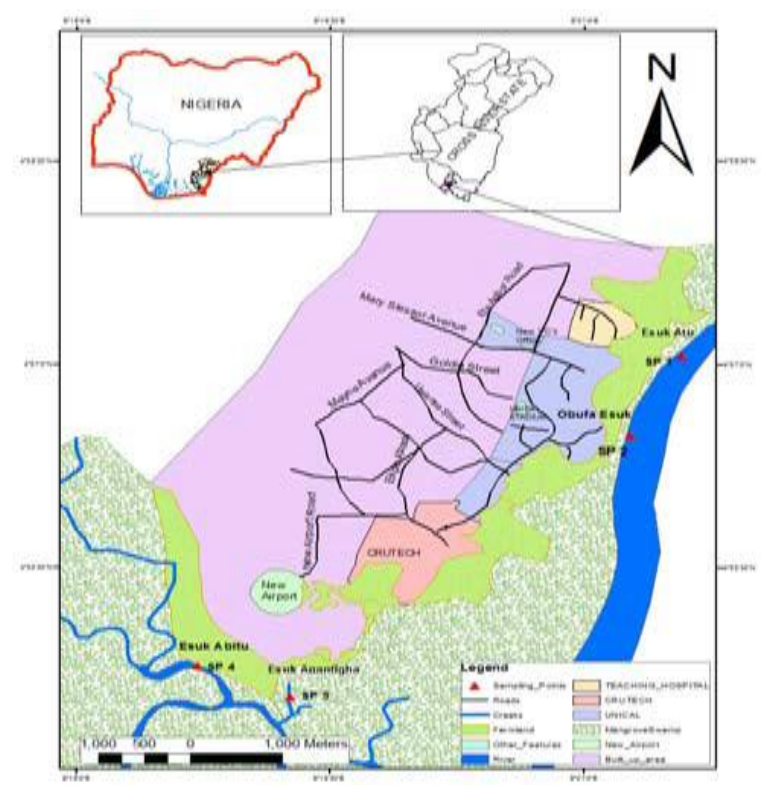

Figure 1: Map of the study area identifying collection points

\section{LABORATORY ANALYSIS}

The fish were preserved in a plastic trough loaded with ice block and was transported to Fisheries and Aquaculture Laboratory in the University of Calabar, Calabar for analysis. The total length (TL) to the nearest $0.1 \mathrm{~cm}$ was taken on the measuring board and weight of each of the fish to the nearest $0.1 \mathrm{~g}$ was measured using a METLAR MT5000D electronic balance. Each fish was cut opened at the visceral region with a pair of scissors and the single gonad which is situated at the left side of the fish was removed and gonad weight was measured to the nearest gram. The fish liver was removed and measured to the nearest gram. Gender was determined by macroscopic examination of gonads according to Moreau (1982).

Fecundity estimation: Fecundity was estimated from direct and total counts of eggs in the ovaries of fish in the most advanced state of development (Njiru, et al., 2006). Each weighed ovary was cut into sub-samples of $1 \mathrm{~g}$. The sub-samples were derived from three sections of the ovary viz: anterior, middle and posterior portions. They were preserved in the modified Gilson fluid inside small glass bottles and shaken periodically to loosen the oocytes, this fluid helps to harden the eggs for counting and diameter measurement. Ovaries of each fish were preserved for a maximum of 5 days before counting the eggs to determine the fecundity (Ekanem et al., 2004). The eggs were rinsed and dewatered using $333 \mu \mathrm{m}$ square mesh screen and low vacuum suction to remove the resulting disintegrated ovarian tissues. The eggs were then dispersed into Petri dishes and any large clumps were gently separated. Counting was done using a stereomicroscope. The eggs per each gram sub-samples were counted. The average for the three sub-samples (anterior, middle, and posterior parts of ovary) was taken as the number of eggs per gram weight of ovary. Therefore, fecundity was calculated by multiplying the total weight of ovary by the number of eggs per gram weight of ovary (Ekanem et al., 2004). The relationship between fecundity and body weight (Wt), fecundity and total length (TL), fecundity and ovary weight. fecundity and Gonadosomatic index (GSI) were estimated using the regression analysis. 
The relationship between fecundity (F) and total length (L) and body weight (W) was represented by the relationship:

$\mathrm{F}=\mathrm{aL}+\mathrm{F}=\mathrm{aW}$

respectively, where F represents fecundity, ' $a$ ' is constant, ' $b$ ' represents the regression co-efficient, while L and W represent total length and body weight respectively.

Scatter diagrams of fecundity against total length, body weight, GSI of the fish were drawn. Egg diameter was measured using calibrated light microscope. Regression lines were fitted on the scatter diagrams by the least square method (Draper and Smith, 1966). A linear regression analysis by means of logarithm transformation was used to study the relationship between fecundity $(\mathrm{F})$ and other variables.

Fish condition: Fish condition was estimated by the

following equation;

$$
\mathrm{K}=\frac{\mathrm{W} \times 100}{\mathrm{~L}^{3}}
$$

Where $\mathrm{K}=$ Condition factor, $\mathrm{W}=$ Weight of fish, $\mathrm{L}=$ Length of fish (cm) and 100 is a constant. (Richter, 2000).

Gonadosomatic index (GSI): Gonadosomatic index (GSI) was calculated according to Bolger, (1989):

$$
\text { GSI }=\frac{\text { Gonad weight } \quad \text { x } 100}{\text { Whole fish weight }}
$$

Hepatosomatic index (HSI): The hepatosomatic index (HSI) was calculated as the percentage of liver weight to whole fish weight. The hepatosomatic index was determined by the formula of Rajaguru, (1992):

$$
\text { HSI = Wt. of liver_x } 100 \mathrm{Wt} \text { of fish }
$$

\section{RESULTS}

A total of $62 \mathrm{H}$. niloticus were sampled from Great Kwa River from January to December. There were 27 males and 34 females. Total length (TL) of all the samples examined ranged from $47.1 \mathrm{~cm}$ to $76.1 \mathrm{~cm}$ while the total weight (TW) ranged from $1056 \mathrm{~g}$ to $3809 \mathrm{~g}$. The highest values in both weight and length were obtained from the female species. Length-size frequency was highest in the class range of 61-65 cm which represented 50.2 percent $(50.2 \%)$ in the pool sample. The least number of specimens was observed in the 76-80 size class. The overall sex ratio of male: female (M: F) was 1:1.26 (table 2.) the female was relatively more than the male but there was no significant difference ( $>0.005$ ). One single gonad (ovary) was seen on the left part of the female fish when dissected 
Table 1: Length-size frequency distribution and size range percentage of Heterotis niloticus in Great Kwa River

\begin{tabular}{lllll}
\hline $\begin{array}{l}\text { Length } \\
\text { class }(\mathbf{c m})\end{array}$ & $\begin{array}{l}\text { Great Kwa } \\
\text { River. No of } \\
\text { male }\end{array}$ & \% value & $\begin{array}{l}\text { Great Kwa River } \\
\text { No. of female }\end{array}$ & $\begin{array}{l}\text { \% } \\
\text { value }\end{array}$ \\
\hline $46-50$ & 5 & 18.6 & 6 & 17.6 \\
$51-55$ & 6 & 22.2 & 4 & 11.8 \\
$56-60$ & 3 & 11.1 & 7 & 20.6 \\
$61-65$ & 8 & 29.6 & 7 & 20.6 \\
$66-70$ & 4 & 14.8 & 6 & 17.7 \\
$71-75$ & 1 & 3.7 & 3 & 8.8 \\
$76-80$ & 0 & 0 & 1 & 2.9 \\
TOTAL & 27 & 100 & 34 & 100 \\
\hline
\end{tabular}

The mean condition factor $(\mathrm{K})$ values for all the months of study showed that the fish were in good condition throughout the year (Table 3) Better condition factor value was obtained in December $(1.1000 \pm 0.07)$ while the least was obtained in the month of July $(0.7950 \pm 0.00)$. The males H. niloticus were in better condition than the female. The monthly mean variations of gonadosomatic index, hepatosomatic index and sex ratio for the fish is shown in table 3. The Hepatosomatic index did not display definite pattern to define spawning seasons but the inverse relationship displayed with gonadosomatic index in some months like February, March, June, September, October, and December depict spawning season. This also shows that H. niloticus is capable of spawning throughout the year.

Fecundity of the fish range from 508 oocytes $(48.1 \mathrm{~cm}$ TL; $1.69 \mathrm{~kg} \mathrm{wt}, 5.7 \mathrm{~g}$ gonad weight) to 7722 oocytes $(69.1 \mathrm{~cm}$ TL, $3.01 \mathrm{~kg}$ wt, $15.2 \mathrm{~g}$ gonad weight) in the Great Kwa River. The relationship between fecundity (F) and Total length, Total weight, gonadosomatic index, and Length-Weight are represented with scattered diagrams fitted with regression line in figures 4-7. Monthly mean fecundity was highest in July (6167 \pm 704$)$ and August (7468 \pm 178$)$ respectively and lowest in June (3471 \pm 1194$)$. The regression equation derived from the scattered diagram in the relationship between fecundity and total weight, total length gonadosomatic index and length-weight is; $\mathrm{F}=6.6231 \mathrm{TW}^{0.837}, \mathrm{R}^{2}=0.2456 ; \mathrm{F}=5.1112 \mathrm{TL}^{1.6367}, \mathrm{R}^{2}=0.1606 ; \mathrm{F}=10680 \mathrm{GSI} \mathrm{I}^{0.9276}, \mathrm{R}^{2}=0.6567$; $\mathrm{TW}=0.4072 \mathrm{TL}^{2.0987}, \mathrm{R}^{2}=0.7533$.

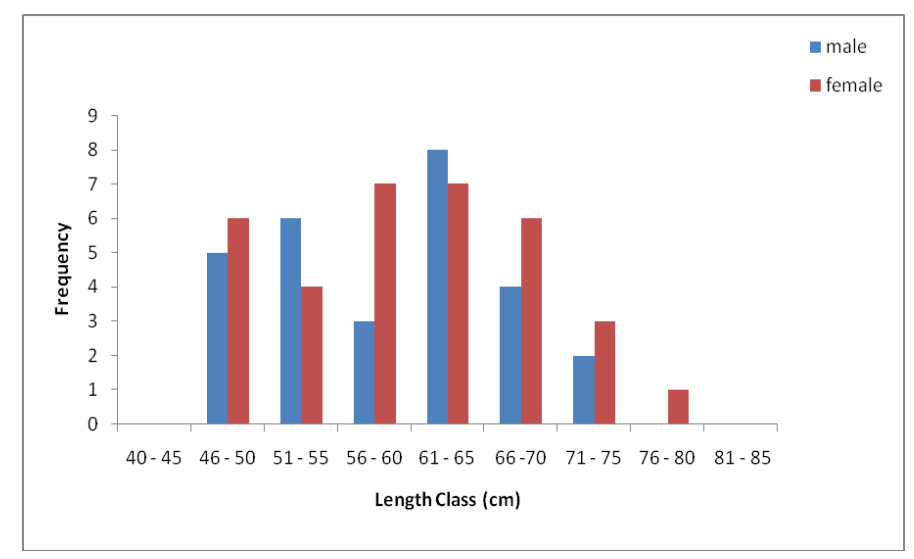

Figure 2: Length-frequency distribution of male/female Heterotis niloticus from Great Kwa River 
Table 2: Mean monthly condition factor $(\mathrm{K})$ of $H$. niloticus in the Great Kwa River

\begin{tabular}{rccc}
\hline Month & \multicolumn{2}{c}{ Great Kwa River } \\
& Male & Pooled Sex \\
\hline Jan & $1.2265 \pm 0.17$ & $0.8980 \pm 0.02$ & $1.0623 \pm 0.12$ \\
Feb & $0.9790 \pm 0.00$ & $1.0483 \pm 0.11$ & $1.0310 \pm 0.08$ \\
Mar & $1.1503 \pm 0.18$ & $1.1170 \pm 0.00$ & $1.1420 \pm 0.13$ \\
Apr & $0.9240 \pm 0.08$ & $1.0753 \pm 0.18$ & $0.9997 \pm 0.09$ \\
May & $0.9930 \pm 0.11$ & $1.0033 \pm 0.08$ & $0.9992 \pm 0.06$ \\
Jun & $0.8997 \pm 0.06$ & $0.7950 \pm 0.00$ & $0.8735 \pm 0.06$ \\
Jul & $1.0806 \pm 0.12$ & $0.9585 \pm 0.14$ & $1.0457 \pm 0.09$ \\
Aug & $0.9620 \pm 0.04$ & $0.9785 \pm 0.08$ & $0.9714 \pm 0.05$ \\
Sep & $1.0033 \pm 0.11$ & $1.1000 \pm 0.07$ & $1.0517 \pm 0.63$ \\
Oct & $1.1752 \pm 0.27$ & $0.8900 \pm 0.00$ & $1.1182 \pm 0.22$ \\
Nov & $0.9360 \pm 0.12$ & $0.8900 \pm 0.02$ & $0.9176 \pm 0.06$ \\
Dec & $0.8930 \pm 0.03$ & $1.2515 \pm 0.16$ & $1.0723 \pm 0.12$ \\
\hline
\end{tabular}

Table 3: Monthly mean values of Gonadosomatic index (GSI), and Hepatosomatic index (HSI) of H.niloticus of Great Kwa River.

\begin{tabular}{cccccc}
\hline Month & Mean GSI & Mean HSI & $\begin{array}{c}\text { Sex Ratio } \\
(\mathbf{M}: \mathbf{F})\end{array}$ & Fecundity & $\begin{array}{l}\text { Egg diameter } \\
(\mathbf{m m})\end{array}$ \\
\hline January & $0.63 \pm 0.09$ & $0.33 \pm 0.04$ & $1: 1$ & $4674 \pm 1118$ & $0.85 \pm 0.02$ \\
February & $0.39 \pm 0.00$ & $0.70 \pm 0.00$ & $3: 1$ & $4572 \pm 0$ & $0.86 \pm 0.02$ \\
March & $0.48 \pm 0.02$ & $0.74 \pm 0.08$ & $1: 3$ & $4911 \pm 738$ & $0.90 \pm 0.01$ \\
April & $0.53 \pm 0.06$ & $0.61 \pm 0.08$ & $1: 1$ & $5046 \pm 606$ & $0.88 \pm 0.02$ \\
May & $0.62 \pm 0.04$ & $0.26 \pm 0.13$ & $1.5: 1$ & $4979 \pm 385$ & $0.92 \pm 0.01$ \\
June & $0.28 \pm 0.04$ & $0.73 \pm 0.15$ & $1: 3$ & $3471 \pm 1194$ & $0.83 \pm 0.02$ \\
July & $0.51 \pm 0.08$ & $0.13 \pm 0.05$ & $1: 2.5$ & $6167 \pm 704$ & $0.85 \pm 0.01$ \\
August & $0.52 \pm 0.07$ & $0.29 \pm 0.07$ & $1.33: 1$ & $7468 \pm 178$ & $0.88 \pm 0.03$ \\
September & $0.32 \pm 0.03$ & $0.77 \pm 0.09$ & $1: 1$ & $4741 \pm 1030$ & $0.87 \pm 0.02$ \\
October & $0.24 \pm 0.03$ & $0.70 \pm 0.05$ & $1: 4$ & $4394 \pm 629$ & $0.85 \pm 0.02$ \\
November & $0.15 \pm 0.04$ & $0.74 \pm 0.12$ & $1: 1.5$ & $4046 \pm 910$ & $0.83 \pm 0.03$ \\
December & $0.38 \pm 0.02$ & $0.63 \pm 0.09$ & 1.1 & $5786 \pm 1503$ & $0.82 \pm 0.01$ \\
\hline
\end{tabular}




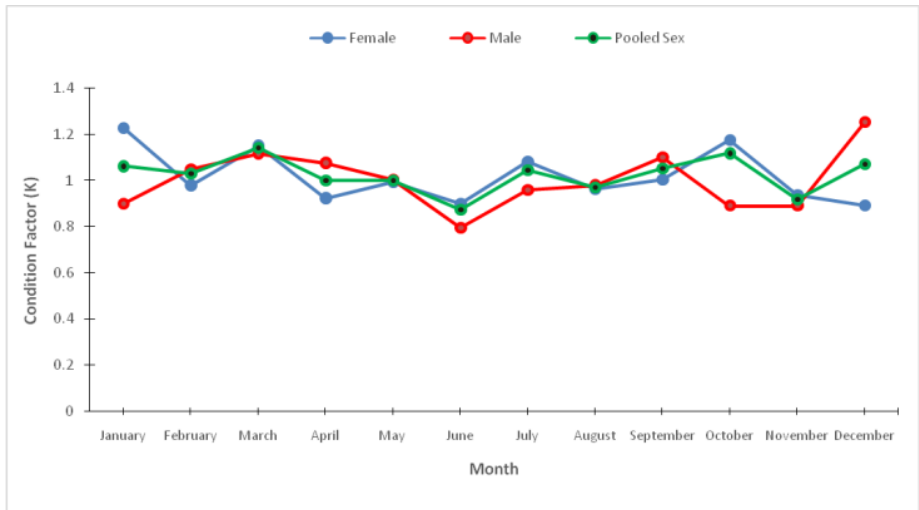

Figure 3: Mean monthly condition factor (K) of H. niloticus in the Great Kwa River

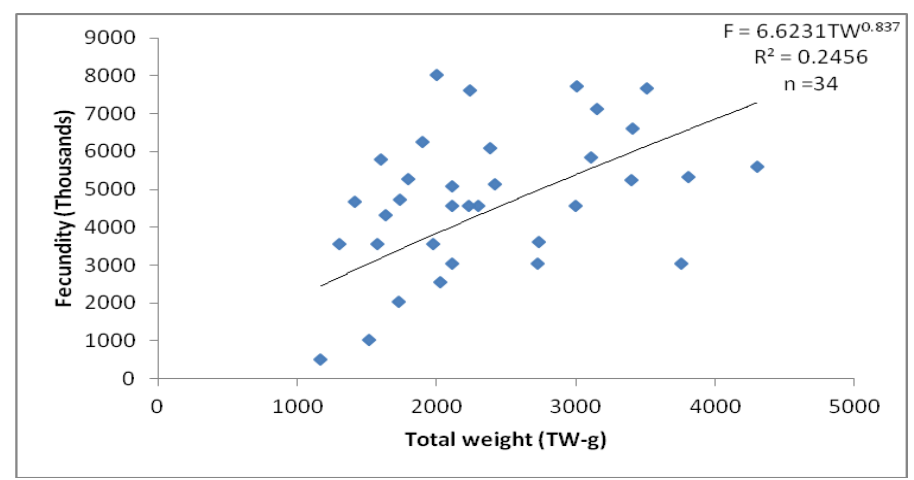

Figure 4: Relationship between fecundity and total weight (TW-g) of H. niloticus from the Great Kwa River

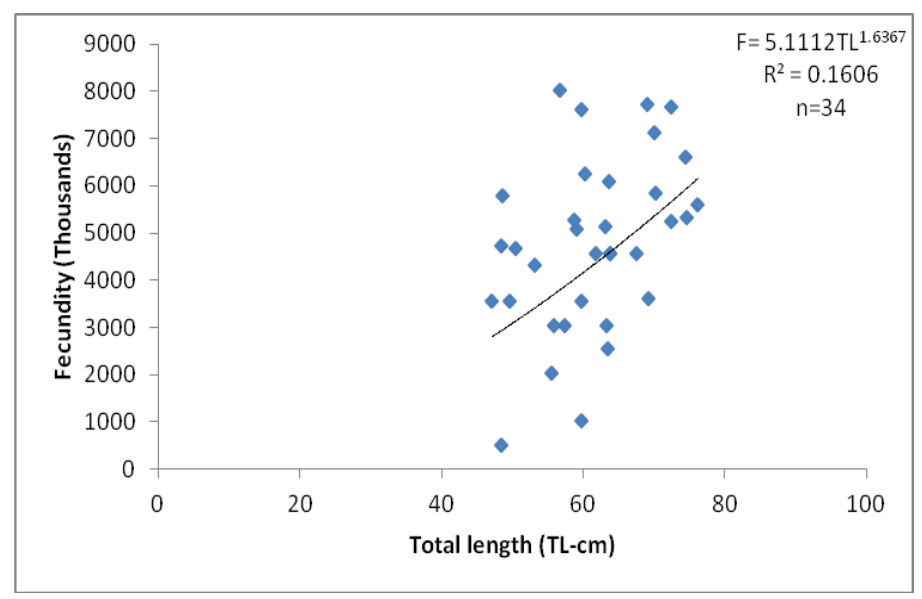

Figure 5: Relationship between fecundity and total length (TL-cm) of $H$. niloticus from the Great Kwa River 


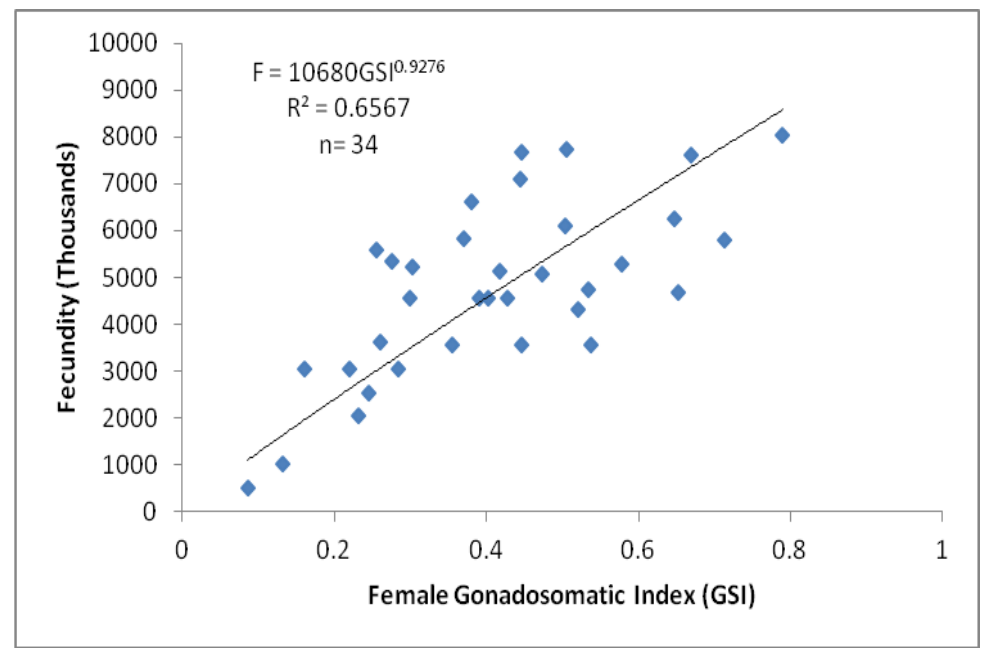

Figure 6: Relationship between fecundity and gonadosomatic index (GSI) of female H. niloticus from the Great Kwa River

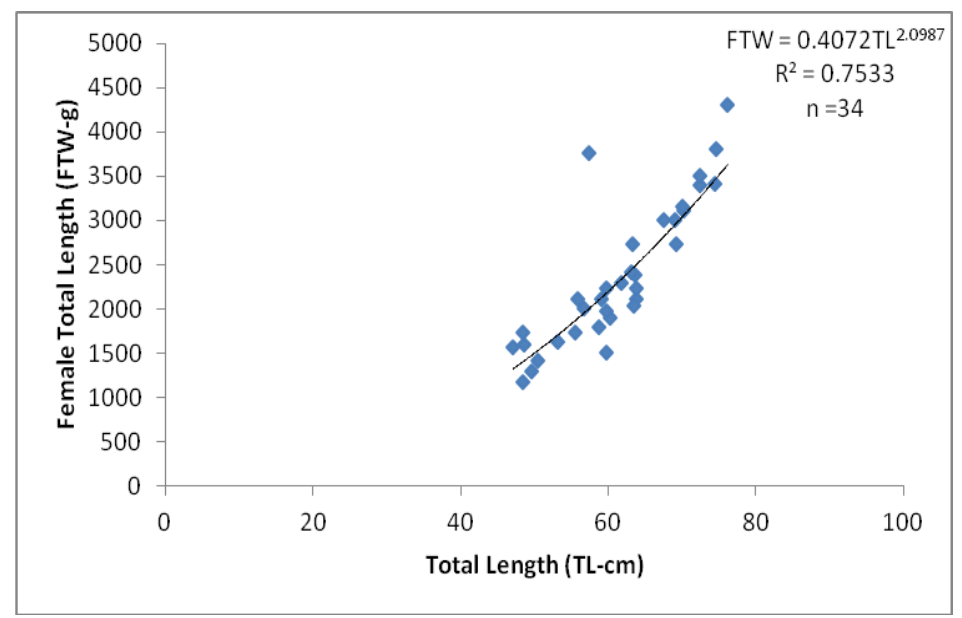

Figure 7: Length-weight relationship (LWR) of female H. niloticus from the Great Kwa River

\section{DISCUSSION}

The distribution of the different length classes recorded during this study showed an adult predominant population, an indication and confirmation of adult Heterotis niloticus habitation of the open water of rivers and lakes while the young are found in the floodplain and swampy area (Adite, et al., 2006; Lopez-Fernander et al., 2003; Dankwa et al., 1999). The population was dominated by adult length class of $61-65 \mathrm{~cm}$ with percentage value of $50.2 \%$. The incessant destruction of the Great Kwa River swampy vegetation for farming activities may also be a contributing factor that hinders breeding activities as breeding grounds are destroyed. The overall dominance of female H. niloticus over the male (sex ratio-M: F) recorded in this study (1:1.26) was not significantly different $(\mathrm{P}>0.05)$. 
Heterotis niloticus were in better condition in the months of January, February, March, September, October and December, this is probably due to better feeding regime which resulted from availability of food materials at the onset and after the rainy season. Better condition was recorded in the males than in the females which may probably be due to the fact that males have better foraging ability and conservation of stored food energy than females. This is comparable to the report of Mgbenka and Eyo (1992) on Clarias gariepinus in Anambra River Basin, Nigeria.

The peak mean value of GSI was recorded in January and May with minor peak in July to August reflecting the spawning seasons. H. niloticus is observed to spawn throughout the year especially during the rainy season this is similar to the finding of Adite et al., (2006). Hepatosomatic index did not show a definite pattern during this study rather showed an inverse relationship with gonadosomatic index (GSI) during the spawning period of this species. This explains the requirement of energy demanded from body organs such as the liver during gonad development, as reported by Ekanem et al., (2004). The highest egg diameter $(0.92 \pm 0.01)$ was recorded in May which has coincided with the performance of GSI, to confirm spawning period. The fecundity regression statistics indicated variability tendencies about functional relationships between fecundity and length, fecundity and total weight, the same was also observed between fecundity and ovary weight, fecundity and gonadosoatic index. The correlation coefficient ( $r$ ) for regression of the above-mentioned variables were significantly different at $(\mathrm{P}<0.05)$. The linear relationship is represented in figures 3 to 7 . The differences that was established between fecundity and length, weight, gonadosomatic index and ovary weight could be due to feeing, environmental condition, season, type of food materials available, spawning period (Fawole and Arawomo, 2000; Ekanem, et al., 2004 and Olele, 2010). The fecundity of H. niloticus (African Bonytongue) in generally could be said to be low when compared to other fish species such as Terapon jarbua with 115,920 eggs (Nandikeswari et al., 2014), Pseudotolithus elongates with 808,911 eggs, (Ekanem et al., 2004), C.striata with 79,436 eggs (Duong et al., 1997), Pomadasys commsersonni with fecundity range of 214,510 -1,421,520 eggs, P. jubelini 37,926 eggs and C. gariepinus fecundity range of 15,667-650,625 eggs for fish size range of 39.5-82.5cm length (Abayomi and Arowomo 1996).

An inverse relationship between the gonadosomatic index and hepatosomatic index was displayed in January, May, July and August indicated high reproductive activity and low energy in the liver. This also showed that $H$. niloticus is all year round spawner. Sex ratio of 1:1 was maintained in the river during the study period.

\section{CONCLUSION}

Great Kwa River present a favourable environmental condition for $\mathrm{H}$. niloticus, with a good mean condition factor suggesting that food was easily available for the fish. The fish was found to be asynchronous breeder with the ability to spawn all year round. There is a log linear relationship between fecundity and weight, length, ovary weight and gonadosomatic index in $H$. niloticus Proper management of the natural water bodies to avoid menace of industrial effluents, oil pollution and destruction of vegetation necessary to ensure better habitat condition for the fish and breeding activities is solicited. 


\section{REFERENCES}

Abayomi, O.S. and Arawomo, G.A. (1996). Sex ratio and fecundity of Clarid catfish (Clarias gariepinus) in Opa reservoir, Ile-Ife, Nigeria. Transactions of the Fisheries Society of Nigeria. pp 122-130.

Adite, A., Winemiller K. O. and Fiogbe, E. D. (2006). Population structure and reproduction of the African bonytongue Heterotis niloticus in the So River-floodplain system, Benin, (West Africa): implications for management. Ecology of Freshwater. Fishes., 15: 30-39.

Akegbejo-Samsons, F.O, George, A. and Agbon, A. O. (2004). Growth, reproduction and aquaculture potential of the African bonytonque fish (Heterotis niloticus) in ponds and reservoirs in coastal south-west states of Nigeria. In: International Conference of the Panafrican Fish and Fisheries Association, Cotonou, Benin.

Bake, G.G. and Sadiku, S.O.E. (2005) Relationship between the basic morphometric measurements and growth pattern of Heterotis niloticus from River Kaduna floodplain. In E. Omotoye (ed) 19th Annual Conference of the Fisheries Society of Nigeria. pp 515-519 Ilorin, Nigeria (FISON).

Cross River Basin Development Authority (1982). Inventory of natural site conditions soil, slope, and hydrology. Land use and vegetation throughout the area of operation of authority.Progress Report No. 4 Nigeria. 145pp

Dankwa, H. R. Abban, E. K. and Teugels, G. G. (1999). Freshwater fishes of Ghana: identification, distribution, ecological and economic importance Annales. Musee. Royal de I'. Afrique. Centrale., Science. Zoologiques., 283:53.

Draper, N. and Smith, H. (1966). Applied regression analysis. John Wiley \& Sons Inc. New York, London, Sydney.

Duong, N. L., Nguyen, V. T. and Leson, T. (1997). Technical aspects for artificial propagation of snakehead (Ophilocephalus striatus,Bloch) in the Mekong Delta. Aquaculture and Fisheries Science Institute - Cantho University.

Ekanem, S. B. (2000). Some reproductive aspects of Chryscithys nigrodigitatus (Lacepede) from Cross River, Nigeria. Naga.The ICLARM quarterly, 23: 24-28.

Ekanem, S. B., Achima, M. and Ekere, M. M. (2004). Studies on some reproductive aspects of Pseudotolithus elongatus in the Cross River estuary, Nigeria. Scientia Marina, 68(2), 265 -271

Ekwu, A. (2008). Observations of H. niloticus in Cross River basin: an introduced species. Special Symposium: International workshop on enhancing freshwater fish species biodiversity research in Africa, 17-21 November. Grahamstow, South Africa.

Fawole, O. O. and Arawomo, G.A.O. (2000). Fecundity of Sarotherodon galilaeus (Pisces: Cichlidae) in the Opa reservoir, Ile-Ife, Nigeria. Revista de biologia tropical, 48(1):22-29.

Lopez-Fernandez, H., Winemiller, K.O., Adite, A., Arrington, D. A. and Layman, C. A. (2003). Fresh water fish diversity in Benin, West Africa, and challenge for its conservation. In: International Conference of the Panafrican Fish and Fisheries Association, Cotonou, Benin.

Levegue, C., Paugy, D. and Teugels, G. G (1990). Faunes de poisons d' Eaux Douces et Saumatres et de' I' Afrique de I' Quest. Tone I. Edition ORSTOM/MRAC Paris. $384 \mathrm{Pp}$ 
Mgbenka and Eyo (1992). Aspects of the biology of Clarias gariepinus in Anambra River Basin, 2: Maturation and condition factor. Journal of Agriculture, Science and Technology 2(1):52-55.

Moreau, J. (1982). Expose synoptique des domēes biologiques sur Heterotis niloticus (Cuvier 1829). Food and Agriculture Organisation synopsis de peches 131: 1-45

Mustapha, M. K. (2010). Heterotis niloticus (Cuvier, 1829), a Threatened Fish Species in Oyun Reservoir, Offa, Nigeria: The Need for its Conservation. Asian Journal of Experimental. Biological. Sciences vol 1(1) 1-7.

Nandikeswari, R., Sambasivam, M. and Anandan, V. (2014). Estimation of Fecundity and Gonadosomatic Index of Terapon jarbua from Pondicherry Coast, India. International Journal of Biological, Food, Veterinary and Agricultural Engineering Vol:8, (1), 61-65.

Njiru, M. Ojuok, J. E., Okey- Owuor, J. B., Ntiba, J. M. and Cowx, I.G. (2004). Some biological aspects and Life History Strategy of Nile tilapia Oreochromis niloticus in Lake Victoria, Kenya. African Journal of Ecology 44, 30-37.

Offem, B.O., Samsons, Y. A. and Omoniyi, I. T. (2008). Reproductive aspects of commom freshwater fishes in the Cross-River State, Nigeria. Journal of Animal and Plant Sciences. 18 (14).

Offem, B. O., Bassey, I. and Ikpi, G. U. (2011). Downstream changes on a tropical fish community structure by effluent from wood processing factory. Journal of Environmental Protection, 2, 982-995.

Olele, N. F. (2010) Reproductive Biology of Sarotherodon galilaeus Artedi, 1757) in Onah lake, Delta State Nigeria. Journal of Applied Sciences Research 6(12):1981-1987.

Rajaguru, A. (1992). Biology of two co-occurring tonguefishes, Cynoglossus arel and C. lida (Pleuronectiformes: Cynoglossidae), from Indian waters. Fishery Bulletin, U.S. 90:328-367 (1992).

Reed, W., Burchard, J., Hopson, A., Jenness, A. j. and Yaro, I (1967). Fish and Fisheries of Northern Nigeria., Zaria, Nigeria. 222p. Gaskya Corporation

Richter, H., C. Lückstädt, U.L. Focken and K. Becker, (2000). An improved procedure to assess fish condition on the basis of length-weight relationships. Archive of Fishery and Marine Research., 48(3): 226-235.

Willis, A. R., Moore, C., Mazon-Moya, M., Krokowski, S., Lambert, C., Robert, T., Mostowy, S. and Sockett, R. E., (2016). Injections of predatory bacteria work alongside host immune cells to treat Shigella infection in Zebrafish larvae. Current Biology 26(24): 3343-3351. DOI: http://dx.doi.org/10.1016/j.cub.2016.09.067 